\title{
A Neutral's Perspective: The Role of the Austrian Armed Forces in Homeland Security
}

\author{
Dr. Johann Frank*
}

\section{Introduction}

The Austrian Armed Forces (AAF) have historically played a significant role in accomplishing security tasks in the domestic sphere. These tasks, extending beyond territorial defense, form an integral part of the constitutionally defined spectrum of possible military missions, and extend back to the times of the Austro-Hungarian Monarchy. These tasks are categorized as law enforcement assistance and disaster relief operations. According to Austrian legal regulations, military activities within the national territory in principle require that "the lawful civil power request its [the military's] cooperation."

On the basis of such a request, however, a relatively wide range of military action is possible. The Security and Defense Doctrine, which was adopted in December 2001, provides the political and strategic guidelines for adapting Austria's security policy to the challenges of the post-Cold War era. It includes plans to further develop and adapt the Cold War-driven concept of "Comprehensive National Defense" to the new risks and challenges posed by a multipolar security environment. A concrete operational model based on this doctrine, including a new definition of the tasks for the AAF in the framework of a modern "homeland security" strategy, does not yet exist. Simultaneously, due to the change of paradigms, Austrian security-political priorities have changed from reactive defense to proactive and multinational stabilization. This functional priority placed on external tasks requires a clear concentration of resources, which causes problems for homeland security tasks due to the low level of defense expenditures. The reorganization of the national security sector will therefore have to include a re-assessment of the financing of national security tasks. While the international profile of the AAF is becoming clearer, the process of defining the military role domestically has been initiated only recently. It is quite obvious that the national policy of deployment of the AAF must be embedded in a comprehensive national concept, and should take into consideration all relevant developments at the regional level (namely, the EU). However, due to its capabilities and special expertise, the AAF is able to make valuable contributions to cope with the new domestic security risks. The qualitative improvements of the transformed AAF ("Bundesheer 2010") will lead to further enhanced military capabilities, especially concerning readiness, command and communication, and defense against nuclear, biological, and chemical attacks.

Dr. Johann Frank is Head of Division for Security Political Analysis within the Austrian Ministry of Defense. Although this paper is based upon official documents, it reflects only the personal views of the author; it does not necessarily reflect the position of the Austrian government.

1 Federal Constitutional Act, Article 79, para 2 B-VG. 


\section{National Policy on the Domestic Employment of the Austrian Armed Forces}

\section{Historical and Conceptual Developments}

The Austrian Armed Forces have three constitutionally defined tasks: ensuring national defense, rendering law enforcement assistance, and conducting disaster relief operations following catastrophes of extraordinary magnitude. The way in which national defense is realized is also constitutionally defined, and is referred to as "Comprehensive National Defense" (CND), which was adopted in 1975 under article 9a B-VG of the Federal Constitutional Act. As stipulated, CND must guarantee national sovereignty, the inviolability and unity of the federal territory, as well as "in particular maintain and protect [Austria's] everlasting neutrality." CND includes military, psychological, civil, and economic national defense. It is, in essence, a comprehensive defense concept following the examples of Sweden and Switzerland. ${ }^{2}$ The embodiment of the CND approach is the "Defense Doctrine,"3 which was adopted by all parliamentary factions on 10 June 1975 and defines in more detail the various elements of CND as well as contains a mandate to develop a National Defense Plan. The National Defense Plan, which was adopted on 19 June 1984, represents the first articulated overall concept for Austria's security with regard to all internal and external threats. ${ }^{4}$ The fact that non-military threats and risks form an integral part of Austria's security concept lent CND a very modern appearance at the time of its drafting. The individual CND areas-military, mental, civil, and economic national defense-are coordinated by the Federal Chancellery, and the respective security goals for each area are defined on the basis of a comprehensive threat scenario. ${ }^{5}$

Fundamental differences among the political parties regarding security issues, which ultimately manifested themselves in diverging assessments of neutrality and NATO, prevented the adaptation of CND and the National Defense Plan to the new geopolitical and security environment of the 1990s. CND and the National Defense

2 See Felix Ermarcora, Österreichische Verfassungslehre, [Austrian Constitutional Law], Vol. 2 (Vienna: Braumüller Verlag, 1980), 41ff.

3 The "Defense Doctrine" is not a law, but rather a parliamentary recommendation to the federal government that honors and implements it as an "administrative maxim."

See Hubert Kempf, "15 Jahre umfassende Landesverteidigung im Bundeskanzleramt [15 Years of Comprehensive National Defense in the Federal Chancellery]," Austrian Military Journal 2:2 (1998): 98.

5 "Psychological national defense" describes the population's information and motivation regarding CND; "economic national defense" means the prevention of economic disruptions and the maintenance of economic capabilities, while "civil national defense" includes the protection of the population and the ability of national institutions to function. "Military national defense" means border protection during conflicts in neighboring states, defense against military attacks, law enforcement operations, and disaster relief. 
Plan are, therefore, still valid relating to legal form and, with regard to their "civil" dimension, ${ }^{6}$ also binding in point of content.

Only the area of military national defense was adapted to the geostrategic situation and given new dimensions, in several steps of structural adaptations. In the course of shifting the priorities of Austria's security policy from reactive comprehensive defense to proactive and multinational environment stabilization, the defense task of the AAF gradually changed from territorial defense (under which rubric the military was intended to field a 300,000-strong force after mobilization), to a flexible, border-oriented protection and defense structure (the force organization in 1998 stood at 110,000 soldiers) to the "militarily domination of own territory and guarantee of national sovereignty" in 2004, which still needs to be defined in more detail. ${ }^{7}$ Planned contributions to international crisis management are increasingly becoming an integral part of the concept of "Extended National Defense." However, the tasks of providing disaster relief and law enforcement assistance have remained unchanged and can, in fact, be traced back to the times of the Austro-Hungarian Monarchy. The traditionally broad spectrum of domestic military assistance tasks is not least due to the fact that Austria does not have any civil defense forces or paramilitary units.

The new Security and Defense Doctrine (SDD), which was passed by Parliament on 12 December 2001, represents a significant step toward the further development of Austria's security policy. ${ }^{8}$ The SDD includes plans to further develop CND into a concept of "Comprehensive Security Precaution"9 (CSP), which foresees the Europeanization of the AAF with regard to the international spectrum of military tasks and, at the

6 "Civil national defense" encompasses measures of disaster relief, self-protection, warning and alert services, shelter construction, and medical provisions, as well as radiation protection. The responsibility for civil protection lies with the public authorities, civil and military organizations, as well as the citizens. The overall coordinating responsibility lies with the Federal Ministry of the Interior. Matters of disaster control are principally the responsibility of the provinces. Actual implementation of the laws is effected in the form of disaster control plans on the provincial, county, and community level. The federal government only takes responsibility under certain circumstances:

- Extensive threats on the national or international level;

- Regional threats that bear the danger of escalating into an extensive threat and are of such great intensity that consequences of national scope may be expected;

- Insufficient manpower or material resources for disaster control in the affected area;

- Need of expertise and information not available to the responsible authorities on short notice;

- Creation of insecurity within the population.

7 Friedrich Hessel, "Strukturentwicklung des Bundesheeres von der "Wende" 1989/90 bis zum Jahr 2003 [Structural development of the AAF between the "turn" of 1989/90 and 2003]," Schriftenreihe der Landesverteidigungsakademie 6 (Vienna, 2004).

8 Austrian Security and Defense Doctrine, General Considerations and Resolution by the Austrian Parliament (Vienna: Federal Chancellery, 2002); available at http://www.bka.gv.at.

9 In the Austrian context, the term "homeland security" can best be interpreted as an equivalent of "Comprehensive Security Precaution." 
national level, recommends the development of a concept for a grand strategy and substrategies for dealing with the new range of security risks and threats. However, due to early elections on the one hand, and the appointment of the Austrian Armed Forces Reform Commission (AAFRC) on the other, the original timetable for developing these new strategies in the areas of foreign policy, defense policy, internal security and economic policy, agriculture, transport, infrastructure, finance, education and information by the end of 2002 could not be met. Their finalization is now envisaged for the second half of 2005. While the CND was organized on a purely national level, and mainly oriented itself on a passive "threat-reaction" concept, the CSP orients itself conceptually on the principles of prevention and European solidarity. However, what remains unchanged is the underlying principle of comprehensive security. According to Austrian constitutional regulations, the final responsibility for the aforementioned sub-strategies remains with the individual ministries, while the Federal Chancellery has a coordinating role only. One of the key challenges will be to ensure inter-ministerial cooperation in a national as well as an international context.

In Austria, homeland security tasks are, therefore, still subsumed under the rubric of the applicable aspects of CND's "civil national defense" on the one hand; on the other hand, the adoption of the sub-strategies, which is expected for 2005, will assign several updated responsibilities for homeland security to various ministries. However, due to the absence of political regulations, as well as the principle of economic efficiency and the limited perception of international terrorism as a threat, the development of a comprehensive, inter-ministerial homeland security strategy would seem only to be possible in the course of a first CSP review process. Until then, homeland security on the national level will remain conceptually underdeveloped, and will only in specific cases - and therefore insufficiently — be coordinated between the ministries. ${ }^{10}$

\section{Security and Defense Doctrine (2001), Grand Strategy and Sub-Strategies}

The new Security and Defense Doctrine (SDD) is a political-strategic conceptual guideline for adapting Austria's security policy to the new international security environment, which has not yet been realized to a large extent. ${ }^{11}$ The emphasis and the direction of the discussion focused on the definition of Austria's future international profile and military commitment. The issue of homeland security did not receive adequate attention, however, and was addressed only in parts after the events of September 11. Despite a number of promising starting points, such as the installation of a National Security Council and the recommendation to develop comprehensive

10 Gustav Gustenau, Sicherheitspolitische Aspekte der Homeland Security aus österreichischer Sicht [Security-political aspects of Homeland security from the Austrian perspective], Vernetzte Sicherheit, Volume 3 (Hamburg: Mittler Verlag, 2004), 134-47.

11 Gustav Gustenau, "Ein Paradigmenwechsel in der österreichischen Außen- und Sicherheitspolitik? - Zur Ausarbeitung einer neuen Sicherheits- und Verteidigungsdoktrin [A paradigmatic shift in Austria's foreign and security policy? - On the elaboration of a new security and defense doctrine]," in Jahrbuch für internationale Sicherheitspolitik 2001 [Yearbook for International Security Policy 2001], edited by Erich Reiter (Hamburg: 2001), 955-64. 
sub-strategies for all areas that are relevant in some way to security issues, there is to date no clear political direction as to how homeland security challenges are to be dealt with on the national level. Thus, the mission for the AAF with respect to their domestic tasks remains in place for the entire new threat spectrum, without being embedded into an overall national homeland security concept or defined priority requirements. In addition to "guaranteeing a military defense capability of operational, enforcementcapable strength" and "developing the capacity to participate in a common [i.e. European] defense," the SDD, in very general terms, recommends that any future defense policy "ensure assistance operation capacities, in order to provide disaster relief, support the Federal Ministry of the Interior in case of terrorist threats, control the borders, and protect sensitive infrastructure." 12

In the course of the AAF Reform Commission's work, the future tasks of the AAF were redefined and received new emphasis. In the final report, the national and international tasks are presented as two equivalent task pillars. However, a functional prioritization of the international tasks is derived from the fact that international requirements are to determine the future structure and capabilities of the AAF. The new organization of the Austrian military is to be implemented by 2010. With it, Austrian defense policy has undergone a paradigm shift, de facto attributing a secondary status to the domestic tasks of the AAF. The main reason for this development is to be found in the nation's limited financial resources. With defense spending of approximately 0.8 percent of the GDP, international operations of the scope intended (at the brigade level or equivalent) can only be managed if Austria's military resources are clearly concentrated. Domestic tasks, therefore, also have to be covered under the international capability and capacity profile. Moreover, such tasks will either increasingly have to be taken over by other institutions, or will require supplementary funding.

The reason for this shift of focus originates from a risk and threat assessment that operates on the premise that wars between Western European nations can be ruled out for the foreseeable future, and that threats to Austria's security can be expected only in the case of failed international stabilization measures. No strategic importance is attributed to the threat of international terrorism. Terrorism is considered to be a subconventional risk ${ }^{13}$ and implicitly, therefore, primarily a police task. With this position, Austria's security and defense policy is following a Europe-wide trend of considering as politically relevant only those risks that can be managed fairly well with the resources at hand. The role of the AAF in fighting terrorism is seen as being rather restricted in Austria, limited to consequence management measures and clearly defined assistance operations.

Nevertheless, in sum the domestic tasks of the AAF, as set forth in the relevant government documents, add up to a very broad spectrum of tasks. The issue of home-

12 Austrian Security and Defense Doctrine, General Considerations and Resolution by the Austrian Parliament (Vienna: Federal Chancellery, 2002); available at http://www.bka.gv.at.

13 "Teilstrategie Verteidigungspolitik," Entwurf ["Sub-Strategy Security Policy," draft] (status as of January 2005). 
land security is mentioned in several passages of the final report of the AAFRC. In connection with the threat and risk analysis, it states:

The Reform Commission recommends attributing an important role to the Austrian Armed Forces, within the framework of providing assistance in police security operations as well as within the framework of national crisis management, in protecting vital civil information and communication technology infrastructure or having backup systems in place, respectively, in the event of disaster or threat.

The Commission further recommends [...] keeping sufficient forces available that can be deployed simultaneously with the contingents deployed abroad, for assistance operations at home, in case of natural or man-made disasters or a terrorist attack as well as for assistance operations in support of the law-enforcement agencies. ${ }^{14}$

With respect to the future force organization and the needed operational capabilities the report states: "The Commission recommends [...] to provide ready forces for tasks at home of 10,000 personnel within the frame of the operational organization/troops. If need be, as for instance in assistance operations, these forces are to be reinforced by call-ups, activating the conscript postponement clause, and particularly by committing militia forces." 15

The sub-strategy document entitled "Defense Policy" (not yet adopted) ${ }^{16}$ defines homeland security-related tasks as follows:

- Contribute to maintaining full sovereignty of the nation's territory and air space, as well as to protect the Austrian population and strategically important infrastructure;

- Aid in law enforcement assistance operations that, particularly with regard to nation-wide tasks, rely on an increased use of technology. Adequate capabilities to provide assistance are to be further developed in the new risk areas, such as terrorism, proliferation, and organized crime as well as information, communication, and technology security, including the necessary intelligence capabilities. This also includes the capabilities to protect constitutionally established institutions, the democratic rights of the population, and maintain order and security in general;

- Develop the ability to cooperate with civil communication systems and support them in maintaining national communication on the basis of an independent information and communication technology component;

- Provide assistance in the wake of natural or man-made disasters in Austria;

- Conduct special operations at home.

14 Bericht der Bundesheerreformkommission - Bundesheer 2010 [Report of the Austrian Armed Forces Reform Commission - AAF 2010], 49-50.

15 Ibid., 51-53.

16 "Teilstrategie Verteidigungspolitik." 
Details on the military implementation and the required force structure are to be elaborated by 2005-06 in the planning document "Management 2010."

\section{Legal Authority for Deployment}

This section deals with the current legislation governing domestic operations by the Austrian military. Article 79 B-VG of the Federal Constitutional Act enumerates all the tasks of the AAF. These are:

- Military national defense (para 1);

- Assistance in law enforcement (para 2);

- Tasks of disaster relief (para 2).

The general legal interpretation works on the premise that military national defense is to be considered the "primary and original core task" of the Austrian armed forces. ${ }^{17}$ Due to the changes in the geostrategic environment in recent years, international AAF operations - as long as they do not cover tasks of international humanitarian assistance or disaster relief explicitly - are also seen as being part of "Extended National Defense." In the event of a military national defense operation or a military-led domestic security operation (see below), special competences and command and control responsibilities as well as rules of engagement and legal regulations apply. The structure of the Austrian military and its capability profile is derived from its original core task. How far a possible primary AAF national task competence would be of relevance to the military's structure would have to be decided on the political level and assessed against the background of a concrete situation, as well as in light of nationally available resources.

\section{Law Enforcement Assistance}

The tasks summarized under the term "law enforcement assistance" are outlined in the Federal Constitution as follows: "The AAF, insofar as the lawful civil power requires its cooperation, has furthermore:

1. Also above and beyond the sphere of the country's military defense:

a. To protect the constitutionally established institutions as well as their capacity to operate and the population's democratic freedoms;

b. To maintain order and security inside the country in general" (Article 79, para 2 B-VG, Federal Constitutional Act).

17 Karl Satzinger, "Assistenzleistungen und Hilfeleistungen des Bundesheeres im Rahmen sicherheitspolizeilicher Aufgaben sowie ihre Rückwirkungen auf die militärische Organisation und Ausbildung. [Assistance and support operations of the AAF within the framework of law enforcement tasks and their implications for the military organization and training]," publication elaborated within the framework of the Higher Quartermaster and Legal Advisor Course (Vienna 1998), 1. 
Law enforcement assistance, therefore, serves two protective purposes: the protection of constitutionally established institutions, and the maintenance of order and security. A constitutionally acceptable request occurs when assistance is requested to provide immediate protection for the following:

- Administrative bodies directly established by the Federal Constitution or recognized as such on the federal or provincial level of execution;

- The highest organs of jurisdiction;

- Proponents of sovereign power, such as authorities on the federal, provincial, and community level.

Whether the phrase "to protect the democratic freedoms of the population"-which was added at a later date (1975) - also includes the protection of the basic constitutional principles ${ }^{18}$ or only covers institutionalized organizational structures is a matter of some controversy. ${ }^{19}$

The second form of assistance refers to "the maintenance of order and security inside the country in general." This used to be an independent military task under the defense legislation of the Austrian part of the Austro-Hungarian Monarchy and, therefore, could be carried out even without being requested by civil authorities. However, with the defense legislation stipulated in the Constitution of the First Republic (19191920), this changed, and military support for law enforcement operations has to be requested by civil authorities. According to current legal understanding, the tasks of maintaining public order and security include all measures aimed at countering general threats to objects of legal protection, which by their character cannot be limited to a specific administrative area (as is the case, for instance, with the inspectorates for fire safety, industrial regulations, or construction regulations). Derived from the wording "in general," the assistance purposes were extended to include subsidiary interventions within the framework of police-administrative tasks to thwart domestic threats. All in all, however, AAF law enforcement operations primarily serve to maintain public order and security as well as provide initial general assistance within the framework of countering threats to objects of legal protection. In addition, assistance operations to counter imminent threats in the field of "security administration" are possible as well. These would include measures in the areas of passport control and immigration, alien registration, surveillance of border crossings into and out of the federal territory, the entire field of weapons, munitions, ammunitions, and explosives, as well as monitoring the press and matters concerning the foundation of associations and gatherings, insofar as such measures do not merely serve to execute administrative procedures but rather are necessary to counter imminent danger. ${ }^{20}$

18 The basic principles of the Austrian Constitution are the republican principle, the democratic principle, and the principle of law and order.

${ }^{20}$ Ibid., 18. 
Independent military intervention for the aforementioned purposes is permitted without request in the event that either the responsible authorities and bodies are prevented from acting by force majeure, and the danger of irreparable damage is imminent; the event of a violent attack; or in the event of violent resistance against AAF units. This constitutionally granted authorization may be regarded as kind of a "stateof-emergency regulation."

The procedures of requesting and obtaining approval for military law enforcement assistance, which requires simple-majority legislative approval, are set forth in Section 2 of the 1990 Defense Act. The authorities and administrative bodies that are entitled to request military assistance in their respective areas of responsibility, provided they are unable to accomplish the tasks assigned to them without AAF assistance, include authorities and bodies on the federal, provincial, and community level. This accounts for a very broad legal framework for AAF law enforcement assistance operations. The following organizations and authorities are entitled to request AAF assistance within their respective areas of responsibility:

- Law enforcement bodies: the Ministry of the Interior, provincial security directorates, district administration authorities, the federal police directorates, mayors, and other community entities;

- Criminal courts, state attorneys, and criminal and administrative law enforcement authorities, in order to protect their activities or maintain the necessary order for carrying out their tasks.

Should an AAF assistance operation require more than 100 soldiers, a directive is needed from the federal government. In cases of imminent danger, the Minister of the Interior (in accordance with the Minister of Defense) can make such a decision, followed by an immediate report to the federal government. An assistance request by civil authorities has to state the expected scope and duration of assistance to be provided.

The "100-men-clause" was introduced by a 1966 amendment to the Defense Act (Federal Law Gazette, No. 185/1966). Rejecting the request is justified if:

- The request is made by an unauthorized person/body;

- Complying with the assistance request would be in breach of penal code regulations;

- The request evidently does not comply with the legal preconditions;

- Other urgent AAF domestic deployment does not permit compliance with the request.

Troop deployment for law enforcement assistance and the use of weapons are regulated under Section 33 of the General Service Regulations for the Austrian military. This paragraph applies to law enforcement assistance operations as well as disaster relief operations. It contains the principal obligation to carry out such operations as much as the capability and deployment modalities permit. The requesting authorities and bodies are expected to define the primary objectives of the assistance operation, while the order to carry out such an operation and the issuance of actual orders is ex- 
clusively the responsibility of the military commanders, who have to seek agreement with the civil authorities. In urgent cases, independent or requested authorization of assistance troops below the "100-men-limit" is the responsibility of the garrison commanders, the provincial military commands within their area of responsibility, and the Land Force Command, particularly if the units to be deployed are located in more than one command area, or if the operation extends over more than one federal province. In cases of imminent danger, the decision (immediately followed by a report) is made by the highest-ranking commander, the garrison's duty officer, or the unit's duty officer.

In assistance operations, soldiers act on behalf of the respective civil authority and thereby assume the legal status of the respective civil body. For the duration of the assistance operation, the soldiers assigned have the same competences as the originally responsible administrative organization. These may, however, be modified in specific cases by the respective federal or provincial legislator.

The use of weapons by assistance troops is only permitted with the explicit consent of the requesting authority, and only after the respective commander has been heard. This restriction on the use of weapons is only suspended in the event of a direct attack against the troops, or in cases of imminent danger. Though the duration of an assistance operation is not specified, unlimited use of military assistance would contradict the principle that every administrative unit should have to carry out its responsibilities by itself. ${ }^{21}$

Personnel and material costs (such as the costs of military material used, or accommodation and food) are charged to the AAF. Only the procurement expenses for equipment assets exclusively serving the specific purpose of the assistance operation are to be covered by the requesting civil authority.

\section{The Relationship between National Defense and Law Enforcement Assistance}

Aside from national defense, the Austrian military may also be asked to assume primary responsibility for certain domestic tasks. The question of distributing responsibilities between the civil authorities and the Ministry of Defense is technically regulated, insofar as the core task of the AAF is the defense of Austria against dangers from outside. Countering domestic dangers is the primary task of the civilian legal powers. In principle, the AAF only becomes active in these areas upon request from and subsidiary to the relevant authorities. The shift of the global security paradigm has, however, blurred the line between interior and exterior security, and has thereby led to a lasting change of the concept of military national defense. This, in turn, has again brought up the question of the distribution of competences between the ministries responsible for security. Objectively, however, the situation in Austria presents itself as follows.

As long as there is no direct military threat from outside to objects of legal protection, the Austrian armed forces will only act in a subsidiary, assistance-providing function. The transition to the military assuming primary responsibility is made only if the

${ }^{21}$ See Walter, Österreichisches Bundesverfassungsrecht [Austrian Federal Constitutional Law], 403. 
constitutionally established institutions and their ability to act as well as the democratic freedoms of the population are threatened from outside, or if events at home that are linked to exterior threats need to be countered, and this can apparently only be done by military means. The solution of the distribution of responsibility is a political decision made by the federal chancellor.

\section{Disaster Relief}

Under Section 2, para 1, sub-para (c) of the Defense Act, the AAF can be employed in disaster relief operations-i.e., following natural or man-made disasters of extraordinary magnitude - if the legal civil power, being unable to cope with the situation with its own means, chooses to draw on them. This also includes taking the most urgent measures to restore administrative and economic activity. In the broadest sense, this may also include measures to restore critical infrastructure; it is immaterial whether the damage or destruction were caused by terrorism or natural catastrophes. Disaster relief assistance can also be provided during a military national defense operation (e.g., assisting in an evacuation of the civilian population, securing/recovering cultural property, etc.)

Authorities on the federal, provincial, and community level-federal ministries, provincial governments, district authorities, and municipal counselors - are all entitled to request military assistance, but these civil authorities have to check if the preconditions for requesting assistance exist. Normally, the request is submitted to the garrison commander, the provincial military command, the Air Force Command, the Land Force Command, the Ministry of Defense, or directly to the minister. Independent military intervention, on the order of a military commander (regardless of the echelon), is only permissible if the civil authorities are prevented from requesting military assistance by force majeure and any further delay would cause irreparable damage to the nation.

An assistance request is to be rejected if it is made by an unauthorized body, if complying with the assistance request would be in breach of penal code regulations, if the request evidently does not match the purpose of the disaster relief operation, or if the troops are needed to carry out other tasks related to national defense. In case of doubt, the request for assistance has to be complied with, and the decision about whether to continue the operation or break it off has to be made by the superior command.

If assistance is provided upon request, the deployed units and soldiers are executive organs of the requesting authority. The commander contacts the requesting authority in order to get a sufficiently accurate picture of the situation and additional information about the type and scope of assistance to be provided in order to achieve the assistance objective defined by the requesting authority. The military commander plans the operation and issues the orders. The operation ends when the requesting authority or body calls for it.

In order to ensure the best chances for the success of an operation, adequately trained and equipped units are to be employed. Particularly suitable for such domestic efforts are engineering and NBC-defense units for technical operations, as well as 
medical units. If there are not enough trained active personnel available, conscripts may be called up, according to Section 35, para 3 of the Defense Act. As an alternative, the conscript postponement clause of the Defense Act (Section 39, para 2) can be activated. For operations following avalanche catastrophes, special avalanche platoons are set up in the affected provinces. For NBC-defense operations each province has, in addition to the units' NBC-defense capabilities, one NBC-defense platoon; nationwide, there are an additional three NBC-defense companies. The civil protection regulations also apply to the troops under deployment. Air units are used for saving human lives as well as for transport and reconnaissance tasks.

If units from different parts of the armed forces are deployed, a suitable commander has to be selected to command the entire force that is engaged in the assistance effort. In cases of disasters of major scope and duration, the assistance troops are led directly by the provincial military command or the Land Force Command respectively, and the Joint Command and Control Staff/Ministry of Defense. For such an eventuality, ready disaster relief staffs are installed in these commands. Each of these consists of a commander and a staff of branch officers, tailored to the specific type of assistance operation. As a rule, the operational staff includes one engineer officer, one NBC-defense officer, one technical officer, and one air operations coordinator. The tasks of those staffs include operational planning, issuance of orders, liaison to the civil authorities on the federal and/or provincial level (in particular to the federal and provincial alert centers, the police, and first responder organizations), coordination of military and civil assistance personnel, coordination of equipment and materiel, branch-specific guidance, operational control, and supply efforts.

The interpretation margin of the currently valid law seems to cover the broadest possible spectrum of AAF domestic tasks. From the legal point of view, there is no reason why the AAF could not be used for the protection/restoration of critical infrastructure, the fight against terrorism, or transport protection.

\section{Use of Weapons within Air Defense}

According to the Militärbefugnisgesetz, air defense and security duties reside under the responsibility of the Ministry of Defense. Beside interception operations by fighter planes, anti-aircraft defense systems on the ground can be employed. The use of airborne weapons is regulated as follows. Fighter planes that are on patrol at the moment are led to the unidentified flying object via the air traffic control center. After hostile intentions (or the misuse of civilian planes for terrorist attacks) have been confirmed, the commander of the two-plane element informs the control center in Pongau about the registration mark of the aircraft in question. The radar-control officer informs the duty officer of the control center. This officer then reports to the responsible officer of the army aviation command, who then gives the order to shoot after he has received authorization from the minister of defense, or the chief of the defense staff if the minister is not available. 


\section{Historical Precedents}

Before 1990, the Austrian Armed Forces had conducted twenty-three operations. This number increased between 1990 and 2001 to sixty-three, with thirteen of those occurring domestically. Except for the military operation at the border to the former Yugoslavia, the other twelve operations lie within the spectrum of law enforcement assistance and disaster relief. The number of working hours expended in the aftermath of disasters grew from 37,000 hours in 1995 to more than 330,000 hours in 1999. This section will provide illustrations of one law enforcement operation and one disaster relief operation; at the close of the section, an assistance operation of the modern type will be presented.

\section{Law Enforcement Assistance Operations}

Since 1955, there have been two major law enforcement assistance operations in Austria in which the military has provided assistance: the "South Tyrol Operation" and the "Burgenland Operation."

The first, conducted in 1967, was a border surveillance operation at the Italian border. It came in response to a continuous series of terrorist attacks in Italy that started in 1961. The fact that the offenders moved from Austria to Italy (or vice versa) before or after the attacks, or were supported by persons living in Austria, led to considerable bilateral tensions between Austria and Italy. The personnel resources of the security organizations in charge of regular border control were not sufficient to ensure complete border control coverage. Thus, on 11 July 1967, the federal government decided to conduct a law enforcement assistance operation with the aim of "reinforcing law enforcement authorities" as well as "preventing illegal traffic of passengers and goods from Austria to Italy and vice versa, in particular with the aim of preventing or clearing up terrorist attacks." The AAF troops involved—primarily infantry units—-were subject to the directives of the minister of the interior. Stopping, searching, and arresting suspects, as well as the use of weapons, were explicitly regulated in a detailed directive issued by the Ministry of the Interior.

The law enforcement operation in Burgenland became necessary after the collapse of communism, when freedom in Eastern Europe led to a considerable increase in the number of illegal border crossings, which once again over-strained the law enforcement agencies. The AAF assistance operation, which was decided on 4 September 1990, was initially limited to ten weeks, but has been regularly prolonged since then, generally for a year at a time. The continuation of this operation will not change until the accession of Austria's Eastern neighboring countries to the Schengen Agreement. The objective of the operation is to prevent illegal border crossings by means of border surveillance as best as possible. To date, more than 280,000 soldiers have served in this assistance operation, detaining and handing over more than 80,000 illegal border crossers to the civil authorities. ${ }^{22}$

${ }^{22}$ Source: http://www.bundesheer.at/cms/artikel.php?ID=1101 (22 November 2004). 


\section{Disaster relief in Galtür}

On 23 February 1999, an 800-meter-wide avalanche destroyed large parts of the Tyrolean village of Galtür, and thirty-one people died. The AAF was asked by the Tyrolean provincial government to provide assistance. The mission order included search and rescue, logistic support for villages isolated by the avalanche, and the evacuation of tourists.

As the national helicopter capacities were not sufficient, an additional twenty-seven foreign helicopters (from the U.S., Germany, Switzerland, and France) were used. Until the end of the mission, on 13 March, six avalanche-mission platoons, three infantry companies, and sixteen Austrian military helicopters were employed in order to rescue twenty-two people and transport 17,000 persons and seventy-five tons of supplies.

\section{Post-9/11}

After the first anthrax-contaminated letters surfaced in the United States mail, insecurity also spread within the Austrian population (as well as among the authorities), and led to the discovery of an increased number of "suspicious substances" in Austria's postal system. Due to the lack of national capacities to verify and, if possible, minimize damage, the Ministry of the Interior, on 13 October 2001, asked the AAF to "provide law enforcement assistance in order to ensure the necessary NBC-defense measures as part of the physical and medical protection of the population. ${ }^{, 23}$ In addition to Austria's standing NBC-defense forces, the alert status was raised for air units to provide specimen transport, for experts of the Armament and Defense Technology Agency's chemical labs for sample analysis, as well as for parts of the military medical service in order to ensure rapid medical treatment. The operational control was based on the principle of "on-site cooperation, with central steering." 24 Following arrangements with the Directorate General for Public Security and the Ministry of the Interior, all assistance requests received by the police were submitted directly to the Ministry of Defense's Operational Center, which issued orders for the respective operations. Operational control was in the hands of the respective provincial military commands. Between 14 October 2001 and 9 December 2002, the military was involved in a total of 414 operations related to the anthrax scare. With the exception of one, all samples taken turned out to be negative. One sample from the U.S. Embassy proved anthrax

${ }^{23}$ BMLV, Operationsabteilung GZ. 67.200/028-5.7/02 (MoD/Operations Division, 2002).

24 Norbert Fürstenhofer and Erwin Richter, "Die Welt vor und nach dem 11. September 2001. Terror und Massenvernichtungswaffen [The World Before and After 11 September 2001. Terrorism and Weapons of Mass Destruction]," in Österreichische Militärische Zeitschrift 2/2002 (Vienna 2002): 175. 
positive, which led to further extensive sample taking from 92 mailbags, as well as decontamination and disposal measures by NBC-defense experts. ${ }^{25}$

\section{Types and Capabilities of Forces}

The Austrian military, with its present structure and capabilities, is the result of several internal reforms and adaptations to international developments. The most recent reform took place in 2002. At present, there are six large commands, nine territorial military commands, and three infantry and two mechanized brigades. In the wake of this most recent reform, the personnel strength after mobilization has been reduced from 110,000 to 55,000. The actual personnel framework of the AAF without mobilization includes 35,000 military personnel (conscripts and professional soldiers) and 9,500 civilian employees. There are no paramilitary or special civil defense forces in Austria. In the future force structure of the AAF, projected to be in place in 2010, a contingent of 10,000 soldiers for domestic operations is foreseen; in cases of emergency, reinforcement through mobilization is possible. Within his legal powers, the defense minister can mobilize up to 5,000 militia troops. Above that level, a decision by the government is required. Mandatory national service will be reduced from eight to six months by January 2006. The tasks for the relevant commands, and the basic duties regarding homeland security, are outlined below.

The majority of the land forces are under control of the Command of the Army (Kommando Landstreitkräfte). The main task of the army is to hold, attack, observe, and protect areas and objects. In addition, the army command is also responsible for training the troops and providing assistance to civilian authorities domestically. The territorial military commands in particular are deployed in cooperation with the civilian authorities in their respective provinces. The Army Aviation Command (Kommando Luftstreitkräfte) controls and employs the majority of the aircraft of the AAF; its main task is controlling Austrian airspace and assisting in troop transport.

The current force structure of the AAF includes: three infantry brigades, two mechanized brigades, two reconnaissance battalions, one antitank battalion, six artillery battalions, three engineer battalions, three anti aircraft battalions, three army aviation regiments, three NBC defense companies, and several combat service and combat service support elements. The number of territorial militia-type infantry battalions will be reduced by a fourth in the coming years, from thirty-six to twenty-seven.

In cases of assistance operations, the organization of the engaged military forces follows a need-driven approach, which means that composition of the forces and capabilities is adapted to the particular situation. Although the successful accomplishment of these missions can only be achieved through the close cooperation of all branches,

${ }^{25}$ See Hermann Lampalzer, "ABC-Terrorismus - eine neue sicherheitspolitische Herausforderung. Beurteilung der Bedrohung und Reaktionskonzepte auf europäischer und österreichischer Ebene [NBC-terrorism - A new security-political challenge. Threat assessment and response concepts on European and Austrian level]," M.A. Thesis, University of Vienna (2003), 117-20. 
specially trained and equipped forces-especially NBC-defense and engineering units - are used more frequently than others.

The NBC-defense system in the Austrian military includes all measures necessary in order to minimize threats in the case of the use of nuclear, biological, or chemical weapons, as well as after the release of hazardous material from civilian sources. NBCdefense troops support civil authorities through detection operations, situational analysis, decontamination missions, and urban search and rescue operations (including fire fighting tasks and water purification). The NBC-defense troops are currently organized into three companies, six territorial NBC-defense platoons, and five platoons at the army airfields. The research, training, and competence center is the NBC-defense school. Increasing the quality and quantity of Austria's NBC-defense capabilities is one of the most likely results of the current reform process of the armed forces.

Besides combat support, one major mission of the engineer troops is disaster relief. The tasks for such scenarios include two elements: the rescue and the recovery phase. The first phase includes the rescue of people, animals, and goods, as well as the prevention of further damage. The recovery phase aims at the restoration of the functionality of private and public infrastructure. Therefore, Austria's engineering forces are kept at high readiness, and should be able to conduct three disaster relief operations simultaneously.

As the primary responsibility for internal security and disaster management rests with the civilian authorities, the capabilities of the AAF should be considered as being complementary to the civilian forces. After the "gendarmerie" and police have been pooled under a new authority, there will be about 28,000 policemen available in total. Austria does not have any special civil defense forces. The "civilian force providers" are the voluntary fire brigades, the Austrian Red Cross, the Worker's Good Samaritan Federation, the Johanniter Accident Assistance, the Maltese Fraternity, and the mountain rescue brigade. Theoretically, around 350,000 persons could be mobilized on a voluntary basis.

\section{National Response Plans and Programs}

\section{National Crisis Management}

The Austrian national crisis management strategy was established in the wake of the 1986 Chernobyl reactor catastrophe. In principle, it is designed for dealing with all extraordinary crises, dangers, and disaster scenarios. It is based on the following facilities and instruments: the coordination committee, two operational centers, the national and provincial warning and alert centers/services, the radiation early warning system (with 336 detection points nationwide), a central computing system, ${ }^{26}$ as well as alert and operational plans (e.g., radiation alert plan, refugee frame plan, medical plans, etc.). These national measures are supplemented by international information-sharing and

26 This computer back-up system can, in case of a crash or other system failure, cover for one or more federal computing centers. 
disaster relief agreements, particularly within the framework of the European Union, as well as by exercises at home or within the framework of the EU and NATO/PfP.

The technical equipment, and in particular its international network, are in urgent need of being updated. ${ }^{27}$ The SDD intends a reevaluation of the instruments of national crisis management. While detailed alert and operational plans for nuclear and conventional damage scenarios have been developed on the basis of the experiences from the Chernobyl incident, no framework plans for terror scenarios involving biological or chemical agents have been developed thus far. Within their own area of responsibility, the provinces, districts, and communities develop their own disaster control plans, danger catalogues, and case-related framework plans, and each administrative level has operational staff ready at short notice. Moreover, the provinces themselves operate information technology-based warning and alert systems. In order to ensure the unity of command and standardized communication between all first responder organizations in an operation, manuals as well as training and exercise concepts are being developed for some areas.

\section{Military Operational Plans}

Due to the provinces' authority in areas concerning disaster response, the provincial military commands play an important role. As an example for military operational planning, the case of the Province of Lower Austria will be used as an illustration.

The operational concept governing the provision of military assistance in cases of disasters is based on modules. ${ }^{28}$ The military operational modules are: Command and Control/Command and Control Support, Engineering, Radioactive Contamination, Chemical Threats, Logistics, Medical Logistics, Special Use, Alpine Operations, Search and Rescue, and Special Alert. This tailor-made strategy has been designed not only to counter the existing threat scenario, but also to ease the consistent pressure of personnel reductions and permit the full use of capacities by means of a flexible response structure.

The Command and Control/Command and Control Support module includes:

- The establishment of the command and control capability of the disaster relief operational staff of the provincial military commands;

- Ensuring press and information services;

- Providing support for deployed assistance units with command and control personnel and assets;

- Ensuring communication with civil authorities;

${ }^{27}$ Gustav Kaudel, Staatliches Krisenmanagement in Österreich [National Crisis Management in Austria] (Vienna: Österreichische Gesellschaft für Landesverteidigung und Sicherheitspolitik [Austrian Society for National Defense and Security Policy], April 1997), 22.

${ }^{28}$ Franz Schmidinger and Werner Suez, "Militärkommando Niederösterreich: Das Katastropheneinsatzkonzept [Provincial Military Command/Lower Austria: Disaster Relief Concept]," Truppendienst , no. 2 (2003): 125-30. 
- Providing support for civil authorities with command and control personnel and experts.

The Engineering module is responsible for:

- Preventing or minimizing damage to property and infrastructure by supporting the construction of protective structures;

- Rescue of persons and animals;

- Preventing/minimizing environmental damage;

- Assistance in the reconstruction of necessary infrastructure.

The Radioactive Contamination module covers:

- Local and regional detection operations;

- Marking, closing off, and controlling radioactively contaminated areas and objects;

- Controlling critical facilities on a case-related basis (e.g., schools, hospitals, etc.);

- Decontamination operations;

- Taking and transporting samples;

- Advising civilian decision-making staffs.

The Chemical Threats element encompasses:

- Marking and closing off areas on a large scale;

- Assisting in evacuations from contaminated areas;

- Transportation of samples;

- Decontamination operations;

- Providing support to minimize environmental damage.

The Logistics module includes:

- Providing logistic support for assistance troops and civilian aid workers;

- Supporting civil authorities in providing emergency supplies for the affected population;

- Making military infrastructure available;

- Support of the authorities in managing large numbers of refugees.

The Medical Logistic module specifically covers:

- Providing medical support to deployed assistance troops;

- Forming disaster relief platoons from military medical facilities;

- Supporting civil authorities with cross-country and/or armored ambulances;

- Supporting authorities after the outbreak of epidemics;

- Reinforcing civil facilities with military medical personnel; 
- Providing psychological care for deployed personnel, affected persons, and their families.

The module known as "Special Use" includes:

- Deployment of assistance companies with light engineer equipment;

- Deployment in personnel-intensive assistance operations;

- Securing evacuated and quarantined areas, as well as recovering material goods;

- Constructing emergency shelters.

The Alpine Operations module is responsible for:

- Alpine operations in winter (avalanches) and in summer (search and rescue);

- Reinforcement/relief of civilian aid workers in longer-lasting operations in Alpine terrain.

The Search and Rescue module carries out:

- Search and rescue operations (conducted by the NBC-defense corps and supported by the engineer corps) following moderate and heavy damage;

- Search and rescue operations in contaminated objects and areas (conducted by the NBC-defense corps);

- Removal of debris following search and rescue operations.

The Special Alert module consists of:

- Assisting in developing civil alert plans;

- Preventive preparation of assistance troops for special danger situations at high readiness status.

\section{Protection of critical infrastructure}

The task of securing critical infrastructure has implicitly been part of the traditional responsibilities of the Austrian Armed Forces (within the framework of Military Support to Civilian Law Enforcement Agencies ${ }^{29}$ ), and was redefined in the new definition of the military's responsibilities. ${ }^{30}$ This military support can be mobilized either in cases of an external threat - and will then be led in parallel with a military defense missionor as an independent operation in cases of public disturbance.

As required by the documents outlining the plans for such efforts, the objects worth securing are classified into different levels of protection, according to national and regional significance. Only objects of maximum value, the breakdown or destruction of

29 In Austria, civilian law enforcement agencies are primarily under the responsibility of the Ministry of the Interior.

30 See Report of the Reform Commission of the Federal Army, 3.1.3, and Sub-strategy on Defense Policy, Draft (January 2005). Source: www.bmlv.gv.at.at/facts/management 2010. 
which would lead to an enduring and persistent impairment of public life, are subject to an unconditional obligation to secure. Objects of maximum value are:

- The national and federal assembly; regional assemblies; the federal government; the federal president and ministers; regional governments; and the High Court;

- Facilities of energy supply companies;

- Information and communication networks;

- Facilities for providing the population with vital goods (e.g., water, medical supplies);

- Facilities for the maintenance of vital transportation infrastructure.

The actual classification is made according to the proposals of the Security Policy Directorates of the provinces, in agreement with the Ministry of the Interior and the Ministry of Defense. For every object requiring security, special "object security sheets" and emergency plans are drafted. The precise mission for the military forces carrying out object security missions will depend on the civilian authority demanding this security. It will certainly contain a threat analysis, an object security data sheet, and a mission statement.

The missions assigned by civil law enforcement agencies could, for instance, include the following operations and tasks ${ }^{31}$ : Protection of objects (surveillance and control, including defense), border monitoring, protection of traffic infrastructure and transports, support of the police in the implementation of checkpoints on roads, support of the police in the management of demonstrations, and escorting missions, which are generally conducted by special forces.

When conducting these missions, military forces basically have to obey the principles set out for the military task of "protection." This kind of mission can be invoked both in cases of a threat against the forces posed by asymmetric warfare in the context of a military operation, and in cases of defense against attacks by irregular forces-i.e., military support to civilian law enforcement agencies in the fight against terrorism. All these military actions have to occur on the condition that public life will continue to follow peacetime principles. In cases of an area (as opposed to object) security operation, a brigade can secure an area of around $40 \times 30 \mathrm{~km}$, guard forty objects requiring protection or defend fifteen facilities, or protect $45-60 \mathrm{~km}$ of state borders. The main actors in this force-intensive type of mission are infantry combat forces, reconnaissance forces, and special operations forces. Pioneer forces are primarily used for hardening the infrastructure. NBC protection forces are kept in a state of readiness for consequence management and search and rescue operations. The range of tasks carried out by a single soldier can include the following duties:

- Identity checks;

31 Compare Military Command "Service regulations for the Federal Army [Truppenführung. Dienstvorschrift für das Bundesheer]," (August 2004), 139. 
- Checks, searches, ${ }^{32}$ and arrest of persons;

- Building road-blocks;

- Stopping and checking vehicles;

- Escort duties.

In cases where the military is providing support to civilian law-enforcement agencies, the soldiers have in principle the same powers as the civilian authorities. However, the soldiers' actual responsibilities should be defined precisely in the administrative directive. If the soldier accomplishes an eminently military task-e.g., a safeguard duty - the Military Powers Act (Militärbefugnisgesetz) applies. In any other cases, the Police Powers $\mathrm{Act}^{33}$ (Sicherheitspolizeigesetz) is applicable to the members of the armed forces. The use of weapons in a military support mission is only authorized for purposes of legal self-defense (defined in $\$ 3$ of the penal code), overpowering of unlawful resistance, forcing a lawful arrest, preventing the escape of an arrested person, or defending against a threat.

\section{Border and Transportation Security}

\section{Border Security}

The political liberalization in the former communist states of Eastern Europe led to a tremendous increase in illegal border crossing and, consequently, to a massive rise in the crime rate in regions that border these states. Following a 1990 decision by the federal government, the Austrian military has been assisting the civil authorities in controlling the nation's borders for about fourteen years in order to prevent illegal immigration. Since 1990, the mission - which was originally limited to ten weeks - has been extended sixteen times, and the operation was expanded towards Austria's border with Hungary and the Czech Republic, as well as parts of the Slovakian border. Under the framework of separated assistance, the AAF has operated at the EU's Schengen border since 1 October 1997 using specially equipped helicopters.

In total, more than 280,000 soldiers have been deployed on such missions thus far. On average, about 2,200 soldiers are deployed at the borders, approximately onefourth of which are "professional soldiers" who serve for about six weeks once a year. The majority of the personnel are conscripts from throughout Austria. In total, more than 80,000 illegal border crossers have been caught, and the preventive effect is calculated to be 80 percent. Despite the status of the neighboring countries as EU members, the mission will be continued until at least 2006. As the force is mainly made up of conscripts, all discussions about shortening the term of mandatory military service

32 Search of persons includes the search of a person and their clothes with the aim of discovering certain objects.

33 In this context, the following provisions appear most significant: $\S 16$ (intelligence-gathering), $\S 21$ (defense from danger), $\S 22$ (prevention of potential attacks), $\S 36$ (denial of entering as certain area), $\S 48$ (securing of persons and things), $\S 49$ (exercise of authority of command and coercion). 
or implementing a professional army have a bearing on this operation. At present, a large number of illegal border-crossers are from Central Asia, Eastern Europe, and the Middle East, as well as a number from Africa and the Balkans. The main route that they follow goes through Slovakia. The irregular migrants are brought close to the border by human trafficking organizations. They then try to cross the border on foot in places where complete control of the border is difficult to exert, due to rough terrain. Once inside Austria, other smugglers pick up the majority of the immigrants, who are then taken into the country's interior.

The leading command for this operation is the territorial military command of Burgenland. It is the objective of the military command to work to curtail illegal immigration in close collaboration with the civil law enforcement forces. The deployed military forces are structured into two assistance contingents, Assistance Commands North and South, including nine companies in total. Both assistance commands control the federal border according to the objectives of the responsible political authorities (Bezirkshauptmannschaften). The primary geographical priority at present is the Slovakian border. In the conduct of the military operation, several important aspects are to be taken into consideration:

- Fulfillment of the tasks formulated by the regional-district-authorities, in close cooperation with the civil law enforcement agencies;

- Avoidance of border violations by Austrian soldiers through clear identification of the borderline;

- Adapting to the permanently changing behavior of the illegal immigrants through shifts between different modes of military operation;

- Prevention of reconnaissance of the Austrian deployment profile through the constant change of patrolling elements;

- Picking up immigrants who have succeeded in crossing the border by rapid covering of prepared positions in "reception lines" in the rear echelon area of operation;

- Rapid transfer of apprehended individuals to the Austrian law enforcement authorities - never to foreign border guards.

During border service, soldiers carry their weapons in "half-loaded" status. The authority, powers, and duties of the soldiers are outlined in a special leaflet issued by the Ministry of the Interior. These include the right to stop, control, search, and arrest people, as well as to use weapons if necessary. The use of weapons is only permitted for self defense or emergency assistance. In case a suspect escapes from a unit's control, the platoon leader must immediately report to the next civil law enforcement office. When an unidentified person is stopped, the first procedure of the soldiers is to search for weapons, in order to ensure their own safety. Money and other objects of value must not be taken away. Then, if possible, the identity of the border-crosser has to be clarified in order to hand over the person to the relevant civilian authorities.

Based on practical experience, the practical preparation for this type of law enforcement operation consists of training beyond the standard military education. These 
standardized exercises include "Stopping of illegal border-crossers," "Searching the terrain," "Hand-over of border-crossers," "Patrolling," and "Contact with large groups of infiltrated people."

\section{Transportation Security}

Some illustrative data may help demonstrate the complexity of transportation security: Austria's railway network includes around 10,700 km of track, and 260 tunnels; the motorway-system has over $2000 \mathrm{~km}$ of road; 15 percent $(350 \mathrm{~km})$ of the Danube River is reserved for commercial use, heading towards four major harbors; Austria's airport infrastructure consist of six major airports, and around ninety airfields.

The responsibility for transportation security is split up between several administrative bodies. Because of privatization, non-official actors are gaining increasing importance in terms of transport infrastructure. Besides the regular duties of airspace control, the AAF also assists the Special Forces in cases of emergencies or accidents that involve dangerous goods (especially nuclear, biological, or chemical elements). Securing critical transport infrastructure during peacetime is not explicitly excluded from the military's sphere of responsibilities, and in general is legally possible. In any case, any use of weapons may only be justified in situations of self-defense or emergency assistance.

The military police units are responsible for the supervision of military discipline and internal security, including military traffic control. They are not comparable with paramilitary forces like the Italian Carabinieri, because they are neither specially trained nor equipped for more demanding security tasks like riot-control or the apprehension of war criminals.

\section{Domestic Counterterrorism}

The role of the Austrian military in terms of counterterrorism is based on constitutional preconditions, because all activities of the AAF need constitutional authorization. In principle, the main duty of the AAF is "military national defense," which is focused on the defense of the nation from external threats. Defense against activities inside the country is possibly included here as well, if these activities are connected with threats from outside and an efficient response requires military measures and means. Examples of an internal threat being connected with an external actor can include an external group providing logistical support or operative guidance for groups engaged in political violence or international terrorist activities inside Austria, especially when they are organized on a large scale, weapons of mass destruction are involved, or air-supported operations are planned or conducted. Especially effective military forces for such operations are the Special Forces Command, NBC-defense troops, as well as the military intelligence services.

The Special Forces are meant to cover those tasks that are not executed by conventional army elements. They are pooled together under the Special Forces Command. They include, among others, the so-called Jagdkommando, paratroopers, combat-divers, bodyguards, and counterterrorism units. The Special Forces Command can also 
support civil authorities in the fight against terrorism. Parts of the command can therefore be used for special intelligence missions, arresting extra-violent persons, destroying weapons, ensuring personal security, securing critical infrastructure, fighting terrorists, and conducting hostage-rescue missions.

The two military secret services are the Heeresnachrichtenamt and the Abwehramt. The duties of the Heeresnachrichtenamt are set out in $\S 20$ Abs. 1 of the Militärbefugnisgesetz, and include acquiring, processing, analyzing, and presenting information on foreign countries or international organizations or other bilateral institutions that are relevant to any aspects or activities of the military. Although the Heeresnachrichtenamt mainly focuses on external developments, their analyses might result in valuable information concerning domestic counterterrorism. However, this aspect is primarily the responsibility of the Bundesamt für Verfassungsschutz und Terrorismusbekämpfung of the Ministry of the Interior.

According to $\S 20$ Abs. 2 of the Militärbefugnisgesetz, the Abwehramt is responsible for "military self-protection" through acquiring, processing, analyzing, and presenting information on activities that might threaten the security of military institutions and operations. Due to its special knowledge and expertise, the Abwehramt can make a valuable contribution to the security of information and communication technology.

\section{Other Civil Support Tasks}

On the basis of the aforementioned legal authority and its existing capabilities, the Austrian armed forces might contribute to an even broader spectrum of domestic missions. Military assistance to EOD and drug interdiction efforts are conducted on a case-by-case basis. The most demanding EOD mission was destroying and decontaminating more than one hundred mustard gas-filled artillery shells from the First World War in 1997-98.

The military's canine unit includes around 250 dogs at the moment. They are used for securing military property at the highest security level (radar-stations, airports, munitions-storage, and closed areas) as well as for detecting drugs and explosives. However, the latter purpose has become increasingly challenging as a consequence of the increasing abuse of drugs and the rise in the number of terror alerts. These dogs are used by special units such as the Jagdkommando and the military police, as well as on missions abroad. Another important field of civil support in which the AAF is involved is providing training facilities and military experts for relevant civilian courses, especially in the field of disaster management and staff training for senior police officers.

Military support for national special security events has not been a significant factor in the past. But the forthcoming Austrian EU presidency in 2006 and Austria's hosting of the European Football Championship in 2008 have initiated a process of evaluation of the future role of the AAF in supporting such events. 


\section{Bibliography}

Ermarcora, Felix. Österreichische Verfassungslehre, (Austrian Constitutional Law). Vol. 2. Vienna: Braumüller Verlag, 1980.

Gustenau, Gustav. Sicherheitspolitische Aspekte der Homeland Security aus österreichischer Sicht ., 2004.

Kaudel, Gustav. Staatliches Krisenmanagement in Österreich [National Crisis Management in Austria] In Vienna: Österreichische Gesellschaft für Landesverteidigung und Sicher-heitspolitik [Austrian Society for National Defense and Security Policy., 1997.

Kempf, Hubert. "15 Jahre umfassende Landesverteidigung im Bundeskanzleramt [15 Years of Comprehensive National Defense in the Federal Chancellery." Austrian Military Journal 2, no. 2 (1998): 98.

Schmidinger, Franz, and Werner Suez. "Militärkommando Niederösterreich: Das Katastro-pheneinsatzkonzept [Provincial Military Command/Lower Austria: Disaster Relief Concept]." Truppendienst 2 (2003). 